\title{
Upaya Peningkatan Motivasi Dan Prestasi Belajar Kimia Melalui Implementasi Model Pembelajaran Jigsaw Pada Pembelajaran Laju Reaksi Kelas Xi IPA 1 SMA Negeri 1 Paguat Tahun Pelajaran 2019/2020
}

\author{
Rahmawaty Tuna \\ Sma Negeri 1 Paguat \\ Rahmawaty.tuna@gmail.com
}

Received: 13 August 2021; Revised: 02 October 2021; Accepted: 14 December 2021

DOI: http://dx.doi.org/10.37905/aksara.8.1.333-342.2022

\begin{abstract}
Abstrak
Penelitian ini merupakan penelitian tindakan kelas yang bertujuan untuk menemukan upaya meningkatkan aktivitas peserta didik melalui pembelajaran kooperatif tipe Jigsaw, untuk meningkatkan prestasi belajar kimia dan respon peserta didik. Peserta didik merupakan subjek pendidikan yang secara aktif mampu membentuk prestasi belajar kimia dalam dirinya. Agar mampu memperoleh prestasi kimia yang baik maka dibutuhkan sikap atau motivasi sebagai bekal ajar belajar dengan baik. Penelitian ini merupakan penelitian tindakan kelas yang dilaksanakan dalam tigas siklus. Subyek penelitian ini adalah peserta didik kelas XI IPA 1 SMA Negeri 1 Paguat. Fokus yang diteliti dalam penelitian ini adalah motivasi dan prestasi belajar kimia peserta didik. Dari hasil penelitian menunjukkan bahwa motivasi dan prestasi belajar kelas XI IPA 1 SMA Negeri 1 Paguat menjadi meningkat yang ditandai dengan peningkatan rerata nilai dari siklus 1 sampai siklus III. Aktivitas peserta didik juga terjadi peningkatan. Oleh sebab itu implementasi pembelajaran model Jigsaw mampu memberikan respon yang baik dan positif bagi peserta didik.
\end{abstract}

Kata Kunci: Peningkatan motivasi, prestasi belajar kimia, Model pembelajaran jigsaw, Laju Reaksi Kimia

\section{PENDAHULUAN}

Rendahnya hasil belajar kimia di kelas XI IPA 1 SMA Negeri 1 Paguat menunjukkan rendahnya pemahaman peserta didik terhadap konsep kimia khususnya pelajaran Laju Reaksi. Proses pembelajaran di kelas selama ini diarahkan pada kemampuan peserta didik untuk menghafal informasi tanpa dituntut untuk terlibat dalam pemecahan masalah khususnya menghubungkan persoalan kimia dengan kehidupan. Selain itu juga permasalahan lainnya anatara lain disebabkan karena sebagian peserta didik lebih banyak menunggu sajian guru dibandingkan mencari dna menemukan sendiri pengetahuan maupun keterampilan yang dibutuhkan. Dominasi guru dalam proses pembelajaran menyebabkan peserta didik lebih bersifat pasif. Aktivitas peserta didik yang dominan adalah mendengarkan dan mencatat penjelasan guru. Peserta didik kurang aktif bertanya dan mengemukakan pendapatnya, mereka juga kurang termotivasi untuk memecahlan masalah secara bersama. Akibat dari keadaan ini menyebabkan kinerja dan prestasi belajar kimia rendah.

Ada banyak variasi yang dapat dilakukan guru dalam model pembelajaran kooperatif. Salah satu diantaranya adalah jigsaw, yang dikembangkan oleh Elliot Aronson dan teman-temannya di Universitas Texas dan kemudian diadaptasi oleh Slavin di Universitas John Hopkins. (Arends, 2001)

Didalam jigsaw, peserta didik dikelompokkan menjadi 4 sampai 6 anggota dimana masing-masing anggota kelompok tersebut mendapat tugas untuk mempelajari 
dan mengerjakan tugas terkait materi tertentu. Setelah mereka menyelesaikan tugas dengan baik, maka anggota dari kelompok yang berbeda dengan materi dan tugas belajar yang sama bertemu dan membentuk kelompok baru yang diberi nama kelompk ahli untuk mendiskusikan materi dan tugas belajar mereka sampai benar-benar menguasainya. Setelah itu mereka kembali ke kelompok asalnya untuk secara bergantian mengajar teman satu kelompok tentang materi masing-masing.

Berdasarkan latar belakang di atas, peneliti tertarik untuk melakukan penelitian dengan judul "Upaya Peningkatan Motivasi dan Prestasi Belajar Kimia melalui Implementasi Model Pembelajaran Jigsaw Pada Pembelajaran Laju Reaksi Kelas XI IPA 1 SMA Negeri 1 Paguat Tahun Pelajaran 2019/2020"

Adapun tujuan penelitian tindakan kelas ini adalah 1. Untuk mengetahui peningkatan kerjasama peserta didik dalam proses pembelajaran kooperatif tipe Jigsaw di kelas XI IPA 1 SMA Negeri 1 Paguat khususnya materi Laju Reaksi 2. Untuk mengetahui sejauh mana peningkatan motivasi dan prestasi belajar kimia khususnya materi laju reaksi di kelas XI IPA 1 SMA Negeri 1 Paguat melalui model pembelajaran kooperatif tipe jigsaw 3. Untuk mengetahui respon peserta didik terhadap model pembelajaran kooperatif tipe jigsaw yang diimplementasikan dalam pembelajaran kimia.

\section{KAJIAN TEORITIS}

Model pembelajaran kooperatif telah dikembangkan dan diteliti dengan membandingkan hasil belajar peserta didik yang belajar dengan model kooperatif dengan hasil belajar peserta didik yang belajar dengan model tradisional. Hasil penelitian menunjukkan keunggulan pembelajaran kooperatif antara lain dilihat dari aspek peserta didik, yaitu memberi peluang kepada peserta didik agar mengemukakan dan membahas suatu pandangan, pengalaman, yang diperoleh peserta didik ketika belajar secara kerja sama dalam merumuskan kearah pandangan kelompok. Model pembelajaran kooperatif ini memungkinkan peserta didik untuk mengembangkan pengetahuan, kemampuan, dan ketrampilan secara penuh dalam suasana belajar yang terbuka dan demokratis.

Walaupun prinsip dasar pembelajaran kooperatif tidak berubah, namun dalam implementasinya ada beberapa variasi dari model tersebut. Dari beberapa variasi dari model tersebut, yang banyak dikembangkan adalah jigsaw. Didalam jigsaw, peserta didik dikelompokkan menjadi 4 sampai 6 anggota dimana masing-masing anggota kelompok tersebut mendapat tugas untuk mempelajari dan mengerjakan tugas terkait dengan materi /topik tertentu. Setelah masing-masimg anggota kelompok menyelesaikan tugasnya dengan baik, maka anggota dari kelompok yang berbeda dengan materi dan tugas belajar yang sama bertemu dan membentuk kelompok baru yang diberi nama kelompok ahli untuk mendiskusikan materi dan tugas belajar mereka, sampai benar-benar menguasai. Selanjutnya mereka kembali kekelompok asalnya untuk secara bergantian mengajar teman satu kelompok tentang materi masing-masing.

Aronso, seperti yang dikutip Isjoni (2007:57) telah mengembangkan model jigsaw dalam penerapannya di kelas. Dalam model jigsaw versi Aronso, kelas dibagi menjadi suatu kelompok kecil yang heterogen yang diberi nama tim jigsaw dan materi /topik dibagi -bagikan sebanyak kelompok menurut jumlah anggota timnya. Tiap - 
tiap tim diberikan satu set materi/ topik yang lengkap masing - masing individu ditugaskan untuk memilih topik mereka. Kemudian peseta didik dipisahkan menjadi kelompok ahli yang terdiri dari seluruh peserta didik yang mempunyai bagian informasi yang sama. Dikelompok ahli peserta didik saling membantu untuk mempersiapkan diri untuk tim jigsaw. Setelah mempelajari materi / topik tersebut kepada teman satu timnya. Untuk mengetahui sejauh mana daya serap masing masing peserta didik dalam mempelajari materi / topik tersebut maka pada tahap akhir pembelajaran, mereka disuruh untuk mengerjakan tes atau kuis.

Guru dapat juga melaksanakan kegiatan presentasi atau diskusi kelas untuk mempertanggung jawabkan keahliannya tentang topik / materi yang mereka pelajari. Tidak kalah pentingnya adalah guru selalu memberikan penghargaan terhadap kelompok atau individu yang menunjukkan prestasi belajar maksimal.

\section{METODE PENELITIAN}

Penelitian ini menggunakan metode PTK yang bertujuan untuk meningkatkan motivasi dan hasil belajar siswa menggunakan model pembelajaran Kooperatif tipe Jigsaw. Penelitian ini dilaksanakan di kelas XI IPA 1 SMA Negeri 1 Paguat Tahun Pelajaran 2019/2020. Penelitian Tindakan Kelas dilaksanakan dalam 3 siklus.

Instrumen adalah alat yang digunakan untuk mengumpulkan data dalam penelitian. Bentuknya dapat berupa tes tertulis, angket, wawancara, dokumentasi dan observasi. Pada penelitian ini ada dua macam instrument yang digunakan yaitu instrumen pembelajaran dan instrument pengumpul data.

Teknik pengumpulan data yang digunakan dalam penelitian tindakan kelas ini yaitu 1. Mengadakan Observasi, 2. Melaksanakan Tes akhir siklus dan Tes Prestasi dan 3. Dokumentasi.

Setiap siswa dalam proses belajar dikatakan tuntas apabila memperoleh nilai > 70 (KKM). Tes kognitif dilakukan setiap akhir siklus yang bertujuan untuk mengetahui hasil belajar siswa. Adapun untuk mengetahui ketuntasan individual maka dapat menggunakan rumus sebagai berikut:

Nilai Akhir $=($ Jumlah jawaban benar $/$ jumlah seluruh soal $) \times 100 \%$

Untuk mengetahui skor rata-rata kelas setiap siklus menggunakan rumus sebagai berikut:

Skor rata-rata $=($ Skor seluruh siswa $/$ jumlah siswa

Ketuntasan klasikal dapat dikatakan telah tercapai apabila nilai siswa memenuhi KKM dengan target pencapaian ideal lebih atau sama dengan $75 \%$ dari jumlah seluruh siswa dalam kelas. Untuk mengetahui ketuntasan secara klasikal dapat menggunakan rumus sebagai berikut:

$\% \mathrm{KKM}=($ Jumlah siswa yang tuntas / jumlah siswa) $\mathrm{x} 100 \%$

Observasi langsung adalah pengamatan yang dilakukan terhadap proses yang terjadi dan langsung dilakukan oleh pengamat.

Setelah data observasi ranah afektif siswa secara kelompok diperoleh, kemudian menentukan persentase jumlah kelompok siswa dengan hasil belajar ranah afektif minimal tinggi digunakan perhitungan sebagai berikut:

Persentase skor rata-rata $=($ Skor aktivitas kelompok $/$ kelompok $) \times 100 \%$ 
Setelah diperoleh perhitungan peneliti dapat menentukan kesimpulan berdasarkan target yang ingin dicapai dalam penelitian ini. Peningkatan hasil belajar siswa aspek afektif selama proses kegiatan pembelajaran dengan menggunakan metode jigsaw.

Analisis kualitatif dilakukan dengan menggunakan deskripsi kata-kata dari hasil pengamatan selama proses kegiatan pembelajaran dengan menggunakan metode Jigsaw.

\section{HASIL DAN PEMBAHASAN}

\section{Hasil Penelitian Siklus 1}

\section{Perencanaan Siklus 1}

Pelaksanana Tindakan pada siklus 1 dilaksanakan dengan metode praktikum.

\section{Pelaksanaan Siklus 1}

\section{Hasil Pengamatan}

1) Guru menggunakan metode ceramah dan tanya jawab, semua peserta didik aktif mencatat tetapi yang aktif menjawab pertanyaan hanya sebagian peserta didik.

2) Saat guru menunjuk peserta didik untuk menjawab pertanyaan, ternyata banyak yang masih belum mengerti mengenai konsep laju reaksi.

3) Saat pelajaran berlangsung separo waktu sebagian peserta didik terlihat bosan. Hasil Angket

\begin{tabular}{|c|c|}
\hline \multicolumn{2}{|c|}{ Pertanyaan } \\
\hline $\begin{array}{l}\text { Apakah anda menyukai pelajaran } \\
\text { materi konsep laju reaksi yang baru } \\
\text { saja anda pelajari? } \\
\text { a. Ya } \\
\text { b. Ragu-Ragu } \\
\text { c. Tidak }\end{array}$ & $\begin{array}{l}\text { Bagaimana menurut anda } \\
\text { pembelajaran yang baru saja anda } \\
\text { pelajari? } \\
\text { a. Jelas } \\
\text { b. Ragu-Ragu } \\
\text { c. Tidak Jelas }\end{array}$ \\
\hline \multicolumn{2}{|c|}{ Jawaban } \\
\hline Ya $: 9$ peserta didik & Jelas : 10 peserta didik \\
\hline Alasannya : & Alasannya : \\
\hline 1. Menyukai Kimia & 1. Bisa memahami \\
\hline 2. Supaya naik kelas & 2. Guru membimbing \\
\hline
\end{tabular}

\begin{tabular}{|c|c|}
\hline 3. Bisa memahami & $\begin{array}{l}\text { membantu kepada peserta } \\
\text { didik yang kurang jelas. }\end{array}$ \\
\hline $\begin{array}{l}\text { Ragu-Ragu : } 9 \text { peserta didik } \\
\text { Alasamnya : } \\
\text { 1. Masih sulit memahami } \\
\text { 2. Membingungkan }\end{array}$ & $\begin{array}{l}\text { Ragu-Ragu : } 5 \text { peserta didik } \\
\text { Alasannya : } \\
\text { 1. Tidak dapat mengingat } \\
\text { banyak hal. } \\
\text { 2. Tidak mongarti dalam } \\
\text { mengingat pelajaran. } \\
\text { 3. Tidak konsentrasi }\end{array}$ \\
\hline $\begin{array}{l}\text { Tidak : } 3 \text { peserta didik } \\
\text { Alasannya : } \\
\text { 1. Malas } \\
\text { 2. Membosankan } \\
\text { 3. Sulit }\end{array}$ & $\begin{array}{l}\text { Tidak jelax : } 6 \text { peserta didik } \\
\text { Alasannya : } \\
\text { 1. Tidak mengerti } \\
\text { 2. Susah }\end{array}$ \\
\hline
\end{tabular}

\section{$\underline{\text { Hasil Tes }}$}

Selain mengisi mengisi angket pada akhir pelajaran, peserta didik juga mengerjakan tes dari soal konsep kimia.

\section{Refleksi}

Hasil observasi kelas, angket dan tes, kemudian direfleksikan.

Beberapa kesimpulan hasil refleksi itu adalah sebagai berikut :

1. Pembelajaran konsep laju reaksi dengan metode ceramah kurang menarik perhatian peserta didik pada karena dalam menjelaskan terlalu cepat.

2. Pembelajaran konsep laju reaksi, materi identifikasi yang menggunakan praktikum sedikit lebih menarik perhatian karena adanya aktifitas dari peserta didik.

\section{Hasil Penelitian Siklus II}

\section{Perencanaan Siklus II}

Pada siklus kedua, rancangan kegiatan pembelajaran menggunakan metode jigsaw, peserta didik dibagi menjadi 5 kelompok asal yang tiap kelompok terdiri dari 4 tim 
ahli (ada satu kelompok yang terdiri 5 peserta didik). Tiap tim ahli mempelajari topik yang berbeda dan mendiskusikan. Selama proses pembelajaran diamati motivasi peserta didik serta bagaimana mempresentasikan materi masing - masing.

\section{Pelaksanaan Siklus II}

Hasil Pengamatan

1) Guru menggunakan metode Jigsaw, peserta didik masih ada yang bingung.

2) Ada beberapa peserta didik yang merasa kesulitan dengan materi Teori Tumbukan.

3) Satu kelompok awalnya ribut merasa kesulitan untuk mempelajari materi tersebut.

\section{$\underline{\text { Hasil Angket }}$}

\begin{tabular}{|c|c|}
\hline \multicolumn{2}{|c|}{ Pertanyaan } \\
\hline $\begin{array}{l}\text { Menurut anda apakah pembelajaran } \\
\text { Teori Tumbukan dengan } \\
\text { menggunakan metode Jigsav } \\
\text { menjadi lebih menarik? } \\
\text { a. Ya } \\
\text { b. Ragu-Ragu } \\
\text { c. Tidak }\end{array}$ & $\begin{array}{l}\text { Bagaimana menurut anda } \\
\text { pembelajaran dengan menggunakan } \\
\text { chart atau gambar dibandingkan } \\
\text { tanpa gambar? } \\
\text { a. Memperjelas } \\
\text { b. Ragu-Ragu } \\
\text { c. Sama Saja }\end{array}$ \\
\hline \multicolumn{2}{|c|}{ Jawaban } \\
\hline $\begin{array}{l}\text { Ya: } 14 \text { peserta didik } \\
\text { Alasannya : } \\
\text { 1. Menyukai Kimia } \\
\text { 2. Supaya naik kelas } \\
\text { 3. Bisa memahami }\end{array}$ & $\begin{array}{l}\text { Jelas : } 14 \text { peserta didik } \\
\text { Alasannya : } \\
\text { 1. Dibandingkan gambar lebih } \\
\text { jelas } \\
\text { 2. Menarik }\end{array}$ \\
\hline $\begin{array}{l}\text { Ragu-Ragu : } 3 \text { pegerta didik } \\
\text { Alasannya : } \\
\text { 1. Biasa saja }\end{array}$ & $\begin{array}{l}\text { Ragu-Ragu : } 7 \text { peserta didik } \\
\text { Alasannya : } \\
\text { 1. Masih kurang paham }\end{array}$ \\
\hline $\begin{array}{l}\text { Tidak : } 4 \text { peserta didik } \\
\text { Alasannya : } \\
\text { 1. Tidak }\end{array}$ & Sama saja : 0 peserta didik \\
\hline
\end{tabular}

Hasil Tes

Pada siklus kedua ini, peserta didik juga mengerjakan tes dari soal teori tumbukan.

\section{Refleksi}

Hasil observasi kelas, angket dan tes, kemudian direfleksikan bersama oleh guru dan observer.

Beberapa kesimpulan hasil refleksi itu adalah sebagai berikut:

1. Pembelajaran menggunakan metode Jigsaw dirasa menyenangkan sehingga mempengaruhi peserta didik.

2. Peneliti/Guru merasa terbantu dengan metode jigsaw, walaupun harus menjelaskan bagaimana cara kerja peserta didik karena masih ada yang kebingungan.

3. Sebagian peserta didik sudah bisa melaksanakan tugas dengan baik.

\section{Hasil Penelitian Siklus III}

\section{Perencanaan Siklus III}

Agar peserta didik lebih termotivasi lagi untuk mengikuti pembelajaran dan lebih paham tentang materi Faktor-Faktor yang mempengaruhi Laju Reaksi dilanjutkan menggunakan metode jigsaw dibuat menjadi 4 kelompok yang terdiri dari 5 tim ahli. 
Pelaksanaan Siklus III

Hasil Pengamatan

1) Peserta didik sudah mulai bisa memahami jigsaw sehingga suasananya kondusif.

2) Suasana diskusi berjalan lebih teratur.

3) Waktu yang diberikan bisa tepat.

\section{Hasil Angket}

\begin{tabular}{|c|c|}
\hline \multicolumn{2}{|c|}{ Pertanyaan } \\
\hline $\begin{array}{l}\text { Menurut anda apakah pembelajaran } \\
\text { Faktor-Faktor yang mempengaruhi } \\
\text { Laju Reaksi dengan dengan } \\
\text { mengsunakan alat peraga dirasa } \\
\text { cukup jelas? } \\
\text { a. Ya } \\
\text { b. Ragu-Ragu } \\
\text { c. Tidak }\end{array}$ & $\begin{array}{l}\text { Sesuai pengetahuan anda tuliskan } \\
\text { kelebihan dan kekurangan } \\
\text { pembelajaran dengan bantuan alat } \\
\text { peraga dibandingkan tampa alat } \\
\text { peraga? } \\
\text { a. Memperjelas } \\
\text { b. Ragu-Ragu } \\
\text { c. Sama Saja }\end{array}$ \\
\hline \multicolumn{2}{|c|}{ Jawaban } \\
\hline $\begin{array}{l}\text { Ya : } 19 \text { peserta didik } \\
\text { Alasamnya : } \\
\text { 1. Lebih santai }\end{array}$ & $\begin{array}{l}\text { Kelebihan = } \\
\text { a. Memperjelas } \\
\text { b. Efektif dan efisien }\end{array}$ \\
\hline $\begin{array}{l}\text { Ragu-Ragu = } 2 \text { pegerta didik } \\
\text { Alasannya : } \\
\text { 1. Masih bingung } \\
\text { 2. Suka hitung-hitungan } \\
\text { 3. Harus mencari buku }\end{array}$ & c. Tidak membosankan \\
\hline Tidalk : $O$ peserta didik & $\begin{array}{l}\text { Kelcurangan = } \\
\text { 1. Alatnya terbatas } \\
\text { 2. Masih ada yang main-main }\end{array}$ \\
\hline
\end{tabular}

\section{Refleksi}

Beberapa kesimpulan hasil refleksi itu adalah sebagai berikut:

1. Peserta didik dengan metode jigsaw lebih termotivasi untuk belajar

2. Adanya rasa tanggung jawab

3. Rasa ingin tahunya meningkat

Dalam aktivitas belajar kimia peserta didik diperoleh dari skor angket yang telah diisi oleh kelas XI IPA 1 sebelum proses pembelajaran. Data prestasi belajar kimia peserta didik diperoleh dari skor mengerjakan tes prestasi belajar kimia yang diujikan pada setiap siklus. Ringkasan data pengetahuan awal dan prestasi belajar kimia peserta didik dapat dilihat pada tabel: 
Tabel 1. Data nilai prestasi siklus 1, Siklus II, Siklus III

\begin{tabular}{|c|c|c|c|c|}
\hline No & Nama & Siklus 1 & Silclus II & Siklus III \\
\hline 1. & A & 75 & 90 & 100 \\
\hline 2. & B & 60 & 70 & 90 \\
\hline 3. & $\mathrm{C}$ & 30 & 50 & 80 \\
\hline 4. & $\mathrm{D}$ & 40 & 60 & 75 \\
\hline 5. & $\bar{E}$ & 50 & 50 & 77 \\
\hline 6. & $\mathrm{~F}$ & 75 & 85 & 100 \\
\hline 7. & $\mathrm{G}$ & 60 & 60 & 85 \\
\hline 8. & $\overline{\mathrm{H}}$ & 50 & 60 & 73 \\
\hline 9. & I & 65 & 75 & 83 \\
\hline 10. & $\mathrm{~J}$ & 35 & 50 & 83 \\
\hline 11. & $\mathrm{~K}$ & 45 & 55 & 83 \\
\hline 12. & L & 30 & 70 & 89 \\
\hline 13. & $\mathrm{M}$ & 40 & 70 & 80 \\
\hline 14. & $\mathrm{~N}$ & 70 & 85 & 100 \\
\hline 15. & $\mathrm{O}$ & 60 & 80 & 100 \\
\hline 16. & $\mathrm{P}$ & 35 & 70 & 87 \\
\hline 17. & $Q$ & 40 & 55 & 70 \\
\hline 18. & $\mathrm{R}$ & 35 & 60 & 80 \\
\hline 19. & $\mathrm{~S}$ & 40 & 55 & 70 \\
\hline 20. & $\mathrm{~T}$ & 65 & 70 & 83 \\
\hline 21. & $\mathrm{U}$ & 65 & 85 & 100 \\
\hline
\end{tabular}

Tabel 2 Perbandingan perolehan nilai tes tiap siklus

\begin{tabular}{|c|c|c|c|c|}
\hline No & Siklus & Siklus 1 & Siklus II & Siklus III \\
\hline 1 & $\begin{array}{l}\text { Perolehan nilai > 7,5 } \\
\text { sebanyak }\end{array}$ & 2 orang (9,5\%) & 6 orang (28,6\%) & 18 orang (85,7\%) \\
\hline 2 & Nilai rata-rata kelas & 5,07 & 6,67 & 8,49 \\
\hline 3 & $\begin{array}{l}\text { Perhitungan daya serap } \\
\text { peserta didik terhadap } \\
\text { materi yang disajikan } \\
\text { pada tiap siklus }\end{array}$ & 50,7 & 66,7 & 84,9 \\
\hline
\end{tabular}

\section{PEMBAHASAN}

Hasil observasi pada siklus I menunjukkan bahwa peserta didik masih merasa asing dengan model pembelajaran kooperatif tipe Jigsaw. Hal ini terlihat pada pertemuan pertama, peserta didik masih kelihatan kaku dalam melakukan prosedur model pembelajaran Jigsaw, sehingga suasana kelas terlihat gaduh. Untuk mengatasinya guru memberikan informasi yang lebih detail kepada peserta didik disaat mereka mulai kebingungan dalam kegiatan pembelajaran. Pemberian informasi dilakukan tidak hanya pertemuan pertama saja melainkan juga pada pertemuan berikutnya. Hasil pengamatan terhadap aktivitas peserta didik dalam kelompok pada 
siklus I, persentase rata-rata aktivitas peserta didik yang memberikan perhatian penuh terhadap informasi yang diberikan hanya sekitar 42,86\%. Dalam aspek ini terlihat bahwa masih ada peserta didik yang kurang memperhatikan penjelasan dari guru. Kemudian pada siklus II, rata - rata peserta didik yang memberikan perhatian diberikan sebesar 66,67\%. Pada siklus III peserta didik yang memperhatikan sebesar 90,18\% ini menunjukkan bahwa metode yang digunakan guru adanya peningkatan.

Hasil observasi terhadap aktivitas peserta didik yang mengerjakan materi LKPD dalam kelompok pada siklus I sebesar 52,38\%, Hal ini disebabkan karena masih ada peserta didik yang malu untuk berdiskusi karena merasa memiliki kemampuan yang kurang dibanding dengan teman sekelompoknya, sebagian peserta didik masih merasa tidak nyaman dengan anggota kelompok barunya yang semula selalu bekerja sama dengan teman sebangkunya, harus menyesuaikan diri dengan kelompok barunya. Hal ini terlihat dari suasana kelas yang gaduh saat kerja sama menyelesaikan soal. untuk perbaikan pada siklus selanjutnya maka guru akan memberikan penilaian kepada peserta didik yang mampu menyelesaikan LKPD dengan benar untuk setiap kelompok selain itu guru juga harus terus membimbing peserta didik dalam kelompok sehingga peserta didik dapat mengerjakan LKSPD dengan terarah dan benar hal ini terlihat persentase aktivitas peserta didik yang mengerjakan LKPD dalam kelompok mengalami peningkatan yaitu $85,71 \%$ pada siklus II. Dan pada siklus III terjadi peningkatan yaitu 95,24\%. Suasana ini mulai terlihat semakin aktifnya peserta didik dalam menyelesaikan LKPD. Hal ini berarti peserta didik semakin aktif dan menyadari pentingnya kerjasama dalam kelompok untuk memberikan nilai terbaik untuk kelompoknya ketika proses pembelajaran tipe Jigsaw ini berlagsung.

Berdasarkan hasil evaluasi yang dilakukan pada siklus I, terlihat bahwa belum mencapai indikator keberhasilan yaitu minimal $75 \%$ peserta didik telah mempunyai nilai 7,5 (Kriteria Ketuntasan Minimal/KKM). Peserta didik yang memperoleh nilai $\geq 7,5$ sebesar 2 orang peserta didik atau 9,5\% dan yang belum mencapai nilai 7,5 sebanyak 19 orang peserta didik atau 90,48\%. Bertitik tolak dari hasil belajar kimia peserta didik pada tindakan siklus I yang belum sepenuhnya mencapai indikator keberhasilan dalam penelitian ini yaitu minimal $75 \%$ peserta didik telah memperoleh nilai minimal 7,5 (Kriteria Ketuntasan Minimal/KKM), maka penelitian ini dilanjutkan pada siklus II model pembelajaran kooperatif tipe Jigsaw kembali dilaksanakan. Peserta didik tetap berada dalam kelompoknya masing-masing sebagaimana pembagian kelompok pada siklus I. Upaya-upaya yang dilakukan oleh guru pada siklus II adalah guru memberikan penghargaan kepada kelompok-kelompok yang mempunyai skor tinggi dan dirangkingkan dari rangking 1 sampai dengan rangking 3 dan guru selalu memberikan motivasi kepada peserta didik. Dengan demikian hal ini terbukti dengan semakin aktifnya peserta didik dalam bekerja kelompok baik dalam kelompok ahli maupun kelompok asal sehingga dari hasil evaluasi yang dilakukan pada siklus II, diketahui hasil belajar peserta didik terjadi peningkatan yaitu peserta didik yang memperoleh nilai $\geq 7,5$ sebanyak 6 orang peserta didik atau 28,6\%. Dan yang belum mencapai nilai > 7,5 sebanyak 15 peserta didik. Pada siklus III, 18 peserta didik memperoleh nilai 7,5 keatas $(85,7 \%) 3$ peserta didik $(14,3 \%)$ memperoleh nilai kurang dari 7,5. Nilai rata-rata yang diperoleh pada siklus III, 8,49 dengan daya serap terhadap materi kimia yang dipelajari yakni sebesar 84,9. 
Peningkatan hasil belajar peserta didik tidak lepas dari keberhasilan guru dalam menerapkan model pembelajaran kooperatif tipe Jigsaw, yang didukung oleh perbaikan proses pelaksanaan model pembelajaran ini yang lebih baik pada tiap siklus. Selanjutnya pada hasil evaluasi yang dilakukan pada siklus I, terlihat juga bahwa nilai rata-rata yang diperoleh dari semua kelompok adalah 50,7, sehingga dapat dinyatakan tingkat keberhasilan peserta didik terhadap proses yang dilakukan dan keberhasilan guru sudah optimal (baik sekali), Selanjutnya pada siklus II, nilai rata - rata hasil belajar peserta didik meningkat menjadi 66,7. Pada siklus III nilai rata - rata hasil belajar peserta didik 84,9. Karena indikator keberhasilan dalam penelitian ini yaitu minimal $75 \%$ peserta didik telah memperoleh nilai $\geq 7,5$ telah tercapai, maka penelitian ini dihentikan pada siklus III. Ini berarti bahwa hipotesis tindakan ini telah terjawab yaitu dengan menggunakan model pembelajaran kooperatif tipe Jigsaw hasil belajar kimia peserta didik kelas XI IPA 1 SMA Negeri 1 Paguat pada pokok bahasan Laju Reaksi dapat ditingkatkan.

Model pembelajaran kooperatif jigsaw tersebut sangat tepat dipakai untuk peserta didik kelas XI IPA 1 dan untuk pembelajaran kimia khususnya, karena memunculkan metode pembelajaran yang bervariasi dan memberikan kesempatan kepada peserta didik untuk belajar secara aktif, penuh kerja sama dan menarik minat peserta didik serta menantang peserta didik untuk berbuat lebih bagus.

Beberapa kelebihan model pembelajaran kooperatif jigsaw:

1. Dapat meningkatkan pemahaman peserta didik. Hal ini terbukti dari rata-rata hasi belajar peserta didik yang menunjukkan adanya perbedaan yang signifikan antara hasil pada tiap siklus.

2. Dapat meningkatkan kerjasama, keaktifan, kemandirian, dan motivasi dalam belajar. Hal ini terbukti dengan respon peserta didik selama pembelajaran berlangsung. Secara psikologis model pembelajaran kooperatif tipe Jigsaw ini memberikan manfaat yang sangat besar terhadap peserta didik, antara lain : (1) memotivasi peserta didik untuk belajar giat karena adanya tekanan dari teman kelompoknya serta menyadari akan penilaian yang berkelanjutan, (2) menghilangkan rasa takut pada anak untuk mengungkapkan pendapatnya dan menjawab pertanyaan, dan (3) menumbuhkan kemampuan kerja sama peserta didik, berfikir kritis dan kemampuan membantu teman. Hal ini sesuai dengan pendapat Khoirul dalam Supriyadi (2003) mengemukakan beberapa tujuan khusus model pembelajaran tipe Jigsaw diantaranya adalah mengkaji kebergantungan positif dalam menyampaikan dan menerima informasi diantara anggota kelompok untuk mendorong kedewasaan berfikir dan menyediakan kesempatan berlatih bicara (dan mendengar) untuk berlatih dalam menyampaikan informasi.

Kendala yang dihadapi adalah input peserta didik di SMA Negeri 1 Paguat yaitu kurangnya kesadaran untuk belajar.

\section{KESIMPULAN}

Berdasarkan hasil penelitian yang telah dilakukan di SMA Negeri 1 Paguat dapat disimpulkan bahwa:

1. Implemtasi model pembelajaran kooperatif tipe jigsaw pada mata pelajaran kimia khususnya pokok bahasan laju reaksi dapat meningkatkan aktivitas belajar 
peserta didik kelas XI IPA 1 SMA Negeri 1 Paguat. Hal ini ditandai dengan meningkatnya aktivitas pada tiap siklus: Siklus 1 (rerata $=52,38 \%$, Siklus II $($ rerata $=85,71 \%$ dan siklus III $($ retata $=95,24 \%)$

2. Penerapan model pembelajaran Jigsaw mampu meningkatkan motivasi dan prestasi belajar kimia baik pada aspek kognitif, afektif, dan psikomotor peserta didik di SMA Negeri 1 Paguat, khususnya pada pokok bahasan laju reaksi kimia. Peningkatan prestasi belajar kimia peserta didik ditandai dengan meningkatnya rerata hasil belajar Kimia dari Siklus I (rerata 50,7) menjadi Siklus II (Rerata = 66,7) dan siklus III (Rerata $=84,9)$.

3. Penerapan pembelajaran model Jigsaw memberikan respon/sikap positif dan menyatakan bahwa pembelajaran model Jigsaw dapat meningkatkan motivasi belajar dari siklus I ke siklus III. Siklus I (9,5\%), Siklus II $(28,6 \%)$, serta siklus III $(84,9)$.

\section{SARAN}

Berdasarkan kesimpulan yang telah dikemukakan, maka dalam kesempatan ini peneliti menyarankan sebagai berikut:

1. Sekolah untuk dapat memfasilitasi sarana dan prasarana penunjang kepada guru-guru yang akan mengimplementasikan di kelas.

2. Peningkatan kreativitas guru perlu diperhatikan dan diupayakan untuk menerapkan model pembelajaran kooperatif tipe jigsaw dalam upaya peningkatan hasil belajar peserta didik.

\section{DAFTAR PUSTAKA}

Adrian. 2004. http://artikel.us/art05-65.html. Metode Mengajar BerdasarkanTipologi Belajar Siswa. 20-10-2004. 14.00

Anita, Lie. 2002. Cooperative Learning. Jakarta: Gramedia.

Arikunto. 1998. Prosedur Penelitian Suatu Pendekatan Praktek. Jakarta: Rineka Cipta.

Budi,Wardono.1998, Hubungan Antara Motivasi Berprestasi Dengan Prestasi Belajar Kimia Siswa Kelas I Cawu II SMU Negeri 3 Dili Tahun Pelajaran 1997/1998, Skripsi Malang, F MIPA IKIP Malang.

Isjoni. 2007. Cooperative Learning. Mengembangkan Kemampuan Belajar Kelompok. Bandung: Alfabeta

Ibrahim. 2000. Pembelajaran Kooperatif. Surabaya: UNESA Press.

Purwanto. 2008. Penerapan Model Kooperatif Tipe Jigsaw sebagai upaya peningkatan Kinerja Dan Prestasi Belajar Fisika di SMK. Jurnal Ilmiah Pendidikan. Wing edisi 2.

Sri Supiyati.1989. Hubungan antara Motivasi Berprestasi dan Bimbingan guru Kimia dengan Prestasi Belajar Kimia siswa kelas II A.1 dan Kelas II.A.2 SMA Negeri 7 KOdya Yogyakarta Tahun 1994. Skripsi Yogyakarta: FMIPA IKIP Yogyakarta.

Ucu Cahyana.dkk, Kimia untuk SMA dan MA kelas X, Jakarta, Piranti, 2007. 